\title{
Olive oil characterization of cv Arauco harvested at different times in areas with early frost in Mendoza, Argentina
}

Running title: Harvest time influence on olive oil cv. Arauco

\author{
Eduardo R. Trentacoste ${ }^{1^{*}}$, Adriana P. Banco ${ }^{1}$, Patricia N. Piccoli ${ }^{2}$, Romina \\ P. Monasterio ${ }^{2}$
}

${ }^{1}$ Estación Experimental Agropecuaria Junín (Instituto Nacional de Tecnología Agropecuaria), Mendoza, Argentina.

${ }^{2}$ Grupo de Bioquímica Vegetal, Instituto de Biología Agrícola de Mendoza

(IBAM), FCA - UNCuyo, CONICET. Almirante Brown 500, Chacras de Coria, Mendoza, Argentina.

${ }^{*}$ Corresponding author: ER Trentacoste. Email:

trentacoste.eduardo@inta.gob.ar

This article has been accepted for publication and undergone full peer review but has not been through the copyediting, typesetting, pagination and proofreading process which may lead to differences between this version and the Version of Record. Please cite this article as doi: 10.1002/jsfa.10029 


\section{Abstract}

BACKGROUND: Arauco is the only olive cultivar autochthonous from Argentina, and little has been reported so far regarding the management of this crop. In this work, variations in fruit and chemical characteristics of olives harvested in a wide range of dates and seasons are reported for this cultivar in two sites of Mendoza province in Central West Argentina.

RESULTS: During the harvest periods evaluated, fruit oil content on dry basis remained maximum and stable, but fruit oil content on fresh basis increased as water content decreased with the delay in harvest. Harvest date modified the maturity index of fruits as well as the oxidative stability and phenolic content of oil. In contrast, the fatty acid profile was not consistently affected by harvest date. Environmental conditions, mainly the occurrence and intensity of frosts, closely influenced oil quality as well as maturity advancement with the delay in harvest.

CONCLUSION: Olives with a maturity index lower than two harvested before mid-May was the most appropriate harvest time in order to obtain Arauco oil with high oil yield and good chemical quality. Fruits harvested after mid-May were exposed to minimum temperatures between $-1.2^{\circ} \mathrm{C}$ and $-4.0^{\circ} \mathrm{C}$, producing oil with low phenolic compounds and oxidative stability.

Keywords: Olea europaea L., maturity index, frost events, fatty acid profile, phenolic compounds

\section{INTRODUCTION}


In recent years, several studies and advertising campaigns that emphasize the nutritional and organoleptic properties of olive oil have encouraged a significant growth in consumption and in planted area within the Mediterranean Basin and other regions such as America, Australia, and China. Olive crop (Olea europaea L.) in Argentina has been cultivated since the early $20^{\text {th }}$ century, but it has expanded considerably since the 1990s. New plantations using foreign cultivars-- particularly Arbequina-- were established in high density (more than 300 trees $^{-1} a^{-1}$ ) adapted to mechanized harvesting. However, some foreign cultivars grown in many regions of Argentina have showed poor adaptation in terms of oil production and quality compared with their original cultivation site. ${ }^{1}$

Arauco or 'Criolla' is an autochthonous cultivar from Argentina that has been recognized in the World Catalog of Olive Varieties. ${ }^{2}$ Arauco is well adapted to local conditions and mainly present in old plantations with traditional management (i.e. low density and manual harvest). ${ }^{3}$ Its production is mainly destined to the elaboration of table olives, although recent studies have revealed the high quality of its oil in terms of fatty acid profile and antioxidant compounds. ${ }^{4,5}$ Notwithstanding this, the cultivar still needs characterization of the oil obtained from different environments of Argentina, as well as the crop management required to increase its quality. This means a holistic effort to value a local genetic resource with potential expansion to new plantations.

It is well known that in olive, fruit oil accumulation and composition are modified during fruit ripening, although the rate at which the chemical parameters vary is strongly influenced by cultivar, environmental conditions (mainly air temperature), crop management, and the interaction of all these components. ${ }^{5,6}$ Bodoira et al. ${ }^{4}$ and Rondanini et al. ${ }^{7}$ observed in Arauco maximum oil content at early fruit ripening with a 
slight change in saturated fatty acids, a reduction in oleic acid and phenolic compounds, and an increase in linoleic acid as fruit ripening advanced. García-Inza et al. ${ }^{8}$ carried out a manipulative experiment in which Arauco olive fruits were exposed during the fruit growing period to increments of $5{ }^{\circ} \mathrm{C}$ and $10{ }^{\circ} \mathrm{C}$ above ambient temperature. The authors observed that the oil fatty acid profile was responsive to air temperature with a greater influence during early fruit growth than close to harvest. The relationship between air temperature and other oil chemical parameters such as phenolic compounds were not explored in these works.

Mendoza is an important olive production region of Argentina. Located in central west Argentina, with 22,000 ha of olive orchards mainly spread between latitude 32 $33^{\circ} \mathrm{S}$, representing $20 \%$ of the total olive surface of the country. The mean daily minimum temperature in Mendoza during autumn (olive harvest season) is $7.5^{\circ} \mathrm{C}$ with high probability of early frost occurrence. ${ }^{9}$ Cold-weather conditions differentiate olive growing in Mendoza from olive growing in the warm valleys of northwestern Argentina including San Juan, La Rioja and Catamarca (28 - $\left.31^{\circ} \mathrm{S}\right)$ provinces, where mean daily minimum temperature ranges between $10.9^{\circ} \mathrm{C}$ and $13.0^{\circ} \mathrm{C}$ in autumn with a lower probability of early frost occurrence. ${ }^{1}$

According to harvest time, Arauco is considered a late-harvest cultivar ${ }^{9,10}$; thus, Mendoza's farmers usually finish harvesting after the autumn frost occurrence. Fruits can be damaged at $-0.4^{\circ} \mathrm{C}$, requiring earlier harvesting to obtain high quality oil. ${ }^{11}$ Fruits with frost damage may be easily affected by diseases, lose water, and the oils obtained from them may have low oxidative stability and, consequently, deteriorated organoleptic properties. ${ }^{12,13}$ Knowledge of changes in oil characteristics during fruit ripening in a wide range of management and environmental conditions is essential for 
an adequate design of a harvest calendar when both oil yield and quality are at a maximum. The aims of this study were to evaluate fruit and oil chemical characteristics of cv Arauco at different harvest times, years, and locations in Mendoza province, as well as to explore the relationships between air temperatures throughout fruit oil accumulation period and oil quality parameters.

\section{MATERIALS AND METHODS}

\section{Site, orchard, and samples}

Two experiments were performed in two orchards. Experiment 1 (Junín) was carried out during the 2006-2007, 2007-2008 and 2008-2009 seasons in an olive orchard of cv Arauco at the experimental field of INTA Junín, Mendoza, Argentina (33 $06^{\prime} \mathrm{S}, 68^{\circ} 09^{\prime} \mathrm{W}, 653$ m.a.s.I). The plantation was established in 1956. Trees are vase trained with $12 \mathrm{~m} \times 12 \mathrm{~m}$ spacing and managed with superficial basin irrigation. The climate of the region is arid with an annual rainfall of $218 \mathrm{~mm}$ (period 1998-2018) concentrated in the summer months, and an average temperature annual of $15.7^{\circ} \mathrm{C}$ and $12.9{ }^{\circ} \mathrm{C}$ during autumn months, for period $1998-2018$. Three trees per harvest time with similar crown volume and high fruit load were selected and harvested from April $20^{\text {th }}$ to July $5^{\text {th }}, 2007$, from May $2^{\text {nd }}$ to June $19^{\text {th }}, 2008$, and from May $13^{\text {th }}$ to July $3^{\text {rd }}$, 2009. A sample of $22 \mathrm{~kg}$ was taken from each tree. At each harvest time, an additional sample of $20 \mathrm{~kg}$ was harvested and used to clean the oil extraction system.

Experiment 2 (Rivadavia) was carried out during the 2015-2016 and 20162017 seasons in a commercial cv Arauco orchard in Rivadavia ( $33^{\circ} 20^{\prime} \mathrm{S}, 68^{\circ} 22^{\prime} \mathrm{W}$, 660 m.a.s.I.), Mendoza, Argentina. The orchard was established in 1984 with trees spaced $10 \mathrm{~m} \times 10 \mathrm{~m}$. Trees are irrigated with a double drip-line to restore $100 \%$ of estimated crop evapotranspiration during the whole growing season. The climate of the 
region is arid with an annual rainfall of $195 \mathrm{~mm}$ concentrated in the summer months and slightly warmer than Junín, with average annual temperatures of $16.3^{\circ} \mathrm{C}$ and 13.6 ${ }^{\circ} \mathrm{C}$ during the autumn months. Within the orchard, 12 homogeneous trees with similar crown volume and high fruit load were selected in February 2016 and 2017 . Four trees for each harvest time were assigned at random. Olives were monthly harvested separately from each tree from April to mid-June in 2016 and 2017. From each tree, a sample of $22 \mathrm{~kg}$ was taken.

The range of harvest dates selected allowed evaluating on a monthly basis the harvest times usual for this cultivar in two of the most important regions of Mendoza from olive growing viewpoint. In addition, the study period included harvests before and after frost events.

\section{Fruit characteristics}

The maturity index was determined in a two-kilogram sample per tree by classifying 100 fruits on a 0 to 7 scale according to skin and pulp colour. Fruits with aqueous consistency as result of frost damage were not used to determine maturity index. A subsample of 50 fruits was used to determine fruit oil concentration in triplicate using the method of Avidan et al. ${ }^{14}$ Fruit oil concentration was estimated as the $\%$ ratio of oil weight and pulp weight on fresh and dry basis. A subsample of 100 fruits was weighed and dried at $60^{\circ} \mathrm{C}$ to constant weight in order to estimate fruit dry weight and water content as $100 \times$ (fresh weight - dry weight) / fresh weight.

\section{Oil extraction}

A fruit sample of $20 \mathrm{~kg}$ from each individual tree was crushed with an Oliomio hammer mill (Toscana Enologica Mori, Tavernelle Val di Pesa, Italy). The olive paste was subjected to malaxation at $25^{\circ} \mathrm{C}$ for 30 minutes. Oil was extracted using a two- 
phase decanter with a work capacity of $30 \mathrm{~kg} \mathrm{~h}^{-1}$. Oil extraction was performed in cold without the addition of water at any phase of the process. Oil was filtered through a thin cotton layer and then transferred to dark glass bottles and stored in darkness at $4{ }^{\circ} \mathrm{C}$. In each studied harvest time, an additional fruit sample in Junín, or one of the four replicates in Rivadavia were used to clean the hammer mill and that oil was not evaluated.

\section{Free acidity and oxidative stability}

To evaluate the physico-chemical quality of the oils obtained, regulated criteria were determined in triplicate for each studied oil sample by using the analytical methodologies described by the International Olive Council (IOC). ${ }^{15}$ Free fatty acid content was measured as percentage of oleic acid (\%), and $\mathrm{K}_{232}$ and $\mathrm{K}_{270}$ extinction coefficients were calculated from absorption at 232 and $270 \mathrm{~nm}$, respectively.

Oil stability was assessed measuring oxidation induction time with Rancimat equipment (Metrohm Ltd., CH10101, Switzerland). A sample of $3 \mathrm{~g}$ of oil was forceoxidized briefly by means of air flow $\left(10 \mathrm{~L} \mathrm{~h}^{-1}\right)$ and heat $\left(110^{\circ} \mathrm{C}\right)$. As a result, the time needed to reach the curve-inflection point was obtained.

\section{Phenolic compound analysis}

The total phenolic compounds from Junín were determined from oil subsamples of $250 \mathrm{~mL}$ following the methodology described by Vázquez-Roncero et al. ${ }^{16}$ The phenolic compounds from Rivadavia oils were determined using the method recommended by IOC. ${ }^{17}$ Two grams of olive oil were weighed, an internal standard solution of syringic acid was added, and the mixture was extracted using $5 \mathrm{~mL}$ methanol/water $(80 / 20 \%, v / v)$ in an ultrasonic bath. Next, it was centrifuged and the 
supernatant filtered and injected in a Dionex Ultimate 3000 HPLC system (California, USA) with a spectrophotometric DAD detector. The gradient indicated by the methodology was applied using water $0.2 \% \mathrm{H}_{3} \mathrm{PO}_{4}(\mathrm{v} / \mathrm{v})$, methanol, and acetonitrile. A column $\mathrm{C}_{18}$ reverse-phase $(4.6 \mathrm{~mm} \times 25 \mathrm{~cm})$, Roc® Restek $(250 \times 4.6 \mathrm{~mm} ; 5 \mu \mathrm{m})$ (Pennsylvania, USA) was used.

\section{Fatty acid composition}

Oil fatty acid composition was determined according to the method proposed by the $\mathrm{IOC} .^{18}$ To do this, $0.1 \mathrm{~g}$ of oil were weighed and $2 \mathrm{~mL}$ of heptane were added and shaken. Then, $0.2 \mathrm{~mL}$ of methanolic potassium hydroxide solution were added and shaken again. The solution was left to decant until the upper solution became clear. The upper layer was put in a vial and $1 \mu \mathrm{L}$ was injected in a Shimadzu GC2010 Plus gas chromatography system (Shimadzu, Japan) using a hydrogen flame ionization detector (FID) and a capillary column ZB-FAME (60 m x $0.25 \mathrm{~mm} \times 0.2 \mu \mathrm{m})($ Zebron, Phenomenex, USA). The detector and injector were set at $260^{\circ} \mathrm{C}$ and $240^{\circ} \mathrm{C}$, respectively. Hydrogen was employed as carrier gas (flow $1.2 \mathrm{~mL} \mathrm{~min}^{-1}$, split ratio of 1:100). The results were expressed as a relative area percentage of total fatty acid methyl esters. Fatty acids were determined by comparing their retention times with those of reference compounds.

The data presented are for major fatty acids: palmitic (16:0), palmitoleic (16:1), stearic (18:0), oleic (18:1), linoleic (18:2), and linolenic (18:3). Minor fatty acids, myristic (14:0), margaric (17:0), margaroleic (17:1), araquidic (20:0), eicosenoic (20:1), behenic (22:0), and lignoceric (24:0) were determined, but are not shown since values were lower than $0.5 \%$ and without any meaningful incidence on oil quality.

\section{Statistical analysis and climate influence}


The data about each experiment and season were independently subjected to variance analysis using Infostat version 1.5. The means were separated using the LSD-test for a level of significance $=0.05$.

Daily meteorological data recorded at an automated weather station located near each site included maximum, minimum, and mean temperatures. From each experiment and season, the average temperature was estimated for the oil synthesis period from January $1^{\text {st }}$ until each harvest date. Pooling data from both experiments, the relationship between air temperature and oil quality was explored using linear or linear-plateau functions with the non-linear routing of GraphPad Prism version 5.01 software.

\section{RESULTS AND DISCUSSION}

\section{Frost event occurrences before harvest time}

Olive plantations in Argentina expand in wide latitudinal (from $33^{\circ} \mathrm{S}$ to $27^{\circ} \mathrm{S}$ ) and altitudinal (from 400 to 1200 m.a.s.I.) gradients with a marked contrast in temperature regimes. ${ }^{1}$ In orchards located at latitudes below $30^{\circ} \mathrm{S}$, olive harvest takes place before the occurrence of slight frosts. In contrast, in olive orchards planted at latitudes higher than $31^{\circ} \mathrm{S}$, as is the case of Mendoza province, harvest frequently takes place under the menace of early frosts. The number and intensity of frost events depended on the sites and seasons. In Junín (Fig. 1A, B and C) during the 2006-2007 season, fruits harvested between April $20^{\text {th }}$ and May $22^{\text {nd }}$ were not exposed to air temperature below $0^{\circ} \mathrm{C}$. Before the June $5^{\text {th }}$ and July $5^{\text {th }}$ harvests, however, there were twenty frost events with a minimum temperature of $-3.4^{\circ} \mathrm{C}$. During the $2007-2008$ season, fruits collected on May $2^{\text {nd }}$ and May $22^{\text {nd }}$ were only exposed to two frost events (minimum temperature $-2.2^{\circ} \mathrm{C}$ ), but before the $19^{\text {th }}$ June harvest, there were fourteen 
frost events, including an extreme minimum temperature of $-4.4^{\circ} \mathrm{C}$. During the $2008-$ 2009 season, fruits harvested on May $13^{\text {th }}$ and June $3^{\text {rd }}$ were not exposed to air temperature below $0{ }^{\circ} \mathrm{C}$, but there were fourteen frost events before the July $3^{\text {rd }}$ harvest (minimum temperature $-3.0^{\circ} \mathrm{C}$ ). In Rivadavia (Fig. 1D and E) during 2015-2016, fruits harvested in mid-April were not exposed to freezing temperatures. Fruits harvested in mid-May and mid-June were exposed to two and fourteen frost events respectively, with minimum temperatures of -2.2 and $-3.2^{\circ} \mathrm{C}$. The $2016-2017$ season was warmer than the 2015-2016 season, and early frost onset occurred after the second harvest date in early May. Fruits harvested in mid-June were exposed to only three slight frosts with a minimum temperature of $-1.2^{\circ} \mathrm{C}$.

Another important difference as a consequence of delayed harvest was a reduction of air temperature between the earliest and latest harvest time (Fig. 1). Across seasons, in Junín the mean temperature from the earliest to the latest harvest date decreased from $20.5^{\circ} \mathrm{C}$ to $17.0^{\circ} \mathrm{C}$. Rivadavia was warmer than Junín, and the mean temperature from the earliest to the latest harvest decreased from $22.4^{\circ} \mathrm{C}$ to $18.3^{\circ} \mathrm{C}$ for the same period.

\section{Fruit characteristics}

Throughout experiment 1, carried out in Junín, and as a consequence of delayed harvest, maturity index (MI) advanced from 1.6 in late-April to 3.4 and 2.8 in mid-July in 2006-2007 and 2008-2009, respectively. However, during the same experiment in 2007-2008 fruits remained yellow-green (MI 1.0) throughput the harvest period (Table 1). In Rivadavia, fruit ripening advanced from 1.2 and 0.6 in mid-April to 2.7 and 1.7 in mid-May in 2015-2016 and 2016-2017 seasons, respectively, remaining at the same maturity stage until mid-June. 
During the 2007-2008 season in Junín, the low and similar maturity index during harvest period could be related with an excessive fruit load of selected trees. Previous studies have shown that fruit ripening develops slower or faster depending on high or low fruit load, respectively. ${ }^{19}$ In addition, the increase in frost events with the delay of harvest could explain the slight change in the fruit color pattern from mid to late harvest date.

Fruit oil content, expressed as \% of dry basis, did not change during the sampling period in both experiments, with the exception of 2007-2008 in Junín, where fruit oil content increased from mid-April to mid-May, and afterwards, remained stable (Tables 1 and 2). Across experiments and seasons, maximum fruit oil content ranged from $41 \%$ to $52 \%$ when fruits had a maturity index between 1.09 and 1.70 (i.e., green yellow). A maturity index higher than two did not imply more oil accumulated in fruits, as previously observed in cv Arauco by Bodoira et al. ${ }^{4}$ In contrast, fruit oil content expressed as \% of fresh basis increased notably as ripening progressed, and in relation with a strong decrease in fruit water content, more markedly in harvests conducted after frost events (Tables 1 and 2 ), as previously noted by Beltrán et al. ${ }^{20}$

\section{Basic quality parameters and oxidative stability}

Oil acidity varied from $0.11 \%$ to $0.44 \%$ at different harvest dates, sites, and seasons. Acidity (\%) and spectrometric UV indexes $\left(\mathrm{K}_{232}\right.$ and $\left.\mathrm{K}_{270}\right)$ covered the normal range for virgin olive oil category (Tables 1 and 2). However, acidity was significantly affected by harvest date during the 2006-2007 season in Junín and 2015-2016 and 2016-2017 seasons in Rivadavia, but a consistent pattern according to the delay in harvest was not observed similarly to previous studies. ${ }^{21,22}$ In addition, oil acidity was not clearly affected in harvests processed after frosts. These results are similar to 
those of other authors, who evaluated oil extracted from fruits (cv. Arbequina) harvested before and after frost occurrence. ${ }^{13,23}$. However, at commercial level, fruits harvested after frosts could lead to a more rapid deterioration than those harvested before frosts. Therefore, in such case, the time elapsed between fruit harvest and processing is a key factor. ${ }^{24}$

Spectrometric UV indexes were measured in oils from Rivadavia, but not in those from Junín. $K_{232}$ values increased from early to late harvest in 2015-2016, but they were not affected in 2016-2017. In contrast, $\mathrm{K}_{270}$ values were similar among harvest dates in 2015-2016 and increased from early to mid- and late- harvest dates in 2016-2017. Contrasting results in spectrometric UV indexes in relation to harvest dates have been previously reported for olive oil. ${ }^{25}$

\section{Oxidative stability and phenolic composition}

Oil oxidative stability was the lowest in late harvest in both Junín and Rivadavia locations (Tables 1 and 2), when fruits were exposed to a large number of frost events with minimum temperatures lower than $-1.2^{\circ} \mathrm{C}$ (Fig. 1). Comparing experiments, Junín showed a more evident oxidative stability decrease toward the last harvest date than Rivadavia, where frost events were less frequent and intense.

The content of phenolic compounds decreased markedly during olive maturation (Fig. 2 A) with the exception of 2016-2017 in Rivadavia where fruits were exposed to only three slight frost events with temperatures higher than $-1.2^{\circ} \mathrm{C}$ after the second harvest time. In both sites, harvests from mid-April to mid-May, before frost events, showed oils with values of phenolic content ranging from 585 to $378 \mathrm{mg} \mathrm{kg}^{-1}$, while phenolic content decreased to values ranging from 272 to $60 \mathrm{mg} \mathrm{kg}^{-1}$ in harvests performed after mid-June when frost were frequent with temperatures below $-3^{\circ} \mathrm{C}$ in 
both Junín and Rivadavia (only 2015-2016) locations. Olive fruit tissues under freezing conditions show damage caused by the ice crystals formed inside parenchyma cells which, in turn, may enhance oxidative degradation of phenolic compounds. ${ }^{11,26}$

The reduction in phenolic compounds as maturity advanced matched previous studies on cv Arauco ${ }^{4}$ and other olive cultivars during advanced ripening stages. ${ }^{12,25-27}$ Pooled data from two experiments and seasons showed that phenolic compounds decreased linearly as maturity index increased (Fig. 2A) in correlation with previously reported data for cvs Barnea and Souri ${ }^{22}$ and cv Nostrana di Brisighella. ${ }^{28}$

According to the relationship between phenolic compounds and air mean temperature, it was observed that phenolic compounds remained stable above a mean temperature of $18^{\circ} \mathrm{C}$. These compounds, however, decreased linearly when the mean mean temperature during the fruit growing period fell below $18^{\circ} \mathrm{C}$ (Fig. 2B). Even though the reduction in phenolic compounds was closely associated to changes in fruit color (i.e., fruit ripening), frost events also played a key role both on phenolic compounds and oil oxidative stability. ${ }^{13,26}$

\section{Fatty acids composition}

Regarding fatty acids, their composition in all the samples tested covered the expected normal range for virgin olive oil (Tables 3 and 4). Oleic acid concentration ranged from $59.3 \%$ to $70.1 \%$, well above the minimum of $52 \%$ indicated by COI. In previous studies conducted on oil from cv Arauco from Northwestern Argentina --a region warmer than Mendoza--, Rondanini et al. ${ }^{7}$ and Ceci and Carelli ${ }^{29}$ reported values of oleic acid around $54 \%$. Higher oleic acid contents were expected in olive oils from Mendoza compared to those from provinces of Northwestern Argentina according 
to manipulative experiments that demonstrated that oleic acid concentration decreased linearly with a fall in average temperatures during the fruit oil accumulation period. ${ }^{8}$

In Junín, fatty acids showed some differences among harvest dates, but did not show a clear pattern with the delay in harvest. Within main fatty acids, the concentrations of palmitic and linoleic acids were significantly affected by harvest date in all the seasons studied. Palmitic acid was significantly higher in the earliest than latest harvest date, in contrast with linoleic acid which was the lowest in early May and the highest in the late harvest dates (June $5^{\text {th }}, 2007$; June $19^{\text {th }}, 2008$ and July $3^{\text {rd }}$, 2009). Meanwhile, stearic, oleic, and palmitoleic acids were more consistently influenced by harvest date in the 2006-2007 than 2007-2008 and 2008-2009 seasons when fruits were harvested in a narrow date range. Monounsaturated/polyunsaturated fatty acid (MUFA/PUFA) and unsaturated/saturated fatty acid (UFA/SFA) ratios were also calculated. Significant differences in ratio values were found among the dates studied. The MUFA/PUFA ratio showed the highest values in olives harvested earlier (from late April to early May) and decreased throughout olive ripening to reach a minimum in the last harvest dates (late June to early July). The UFA/SFA ratio showed the opposite pattern.

In Rivadavia, the fatty acid profile, MUFA/PUFA, and UFA/SFA ratios showed more variation in $2015-2016$ than $2016-2017$ when the temperature among harvest times was similar and frost events did not occur. The oil fatty acid profile did not show a clear trend throughout the fruit maturity process, similar to that observed in oil from Junín. The results obtained in this study were consistent with previous reports of studies carried out in a wide range of olive cultivars where harvest date did not play a key role on fatty acid profile. ${ }^{23}$ 
Furthermore, it is well-known that fatty acid composition varies according to genotype and environmental factors. ${ }^{5,7,8}$ By pooling data from both experiments and seasons, the UFA/SFA ratio was related with the daily mean air temperature measured from January $1^{\text {st }}$ until harvest (Fig. $2 \mathrm{C}$ ). No relationships were found between the MUFA/PUFA ratio and the mean air temperature (data not shown). The UFA/SFA ratio decreased linearly with increases in mean temperature over the fruit growing season. Thus, fatty acid composition changes during fruit ripening were closely related to variations in environmental conditions during that period. ${ }^{8}$ In this study, the fatty acid profile showed not evident influence of frost fruit damage similar to what was reported in cv Arbequina harvested in the temperate Mediterranean Catalonia area. ${ }^{13}$

\section{CONCLUSIONS}

Maximum fruit oil accumulation of the Argentinian Arauco cultivar grown in two sites of Mendoza was related to an early maturity index lower than 2.0. Harvests delayed after mid-April increased fruit oil content in fresh basis by water losses without net oil accumulation. Free acidity and spectrophotometric UV indexes remained similar over the harvest study period within $\mathrm{COI}$ limits for virgin olive oil. Arauco oil showed oleic acid concentration higher than $60 \%$ in the environmental conditions of Mendoza, regardless of harvest date. Phenolic compounds in the oil decreased with an increase in fruit ripening and a decrease in air temperature among harvest dates, locations, and seasons. The UFA/SFA ratio decreased as temperature dropped without any relation to fruit maturity stage. Early harvest before mid-May appears more suitable to produce Arauco oil of high chemical quality in Mendoza, regardless of fruit ripening degree. The oil extracted from olives harvested after mid-May could have low phenolic compounds, oxidative stability, and UFA/SFA ratio with a subsequent deterioration of oil quality 
related to a higher frequency of frost events with minimum temperatures below $-1.2{ }^{\circ} \mathrm{C}$ in Mendoza province.

\section{ACKNOWLEDGEMENTS}

The authors would like to express their gratitude to Carlos Puertas, Octavio Contreras-Zanessi, Walter Galarza, and Vanesa Lucero for their valuable assistance with olive collection and laboratory analysis. The authors are also grateful for the funds provided by SPU, MECCyT (SPU-44-143-051) to R.P.M.

\section{REFERENCES}

1. Torres M, Pierantozzi P, Searles P, Rousseaux MC, García-Inza G, Miserere A, Bodoria R, Contreras C, and Maestri D, Olive cultivation in the southern hemisphere: flowering, water requirements and oil quality responses to new crop environments. Front Plant Sci 8: 1830 (2017).

2. Bartolini G, Prevost G, Messeri C, Carignani G, and Menini UG, Olive germplasm. Cultivars and World-wide collections, FAO, Rome (1998).

3. Trentacoste ER, and Puertas CM, Preliminary characterization and morphoagronomic evaluation of the olive germplasm collection of the Mendoza province (Argentina). Euphytica 177: 99-109 (2011).

4. Bodoira R, Torres M, Pierantozzi P, Taticchi A, Servili M, and Maestri D, Oil biogenesis and antioxidant compounds from "Arauco" olive (Olea europaea L.) cultivar during fruit development and ripening. Eur J Lipid Sci Technol 117: 377-388 (2015). 
5. Monasterio RP, Olmo-García L, Bajoub A, Fernández-Gutiérrez A, and CarrascoPancorbo A, Phenolic compounds profiling of virgin olive oils from different varieties cultivated in Mendoza, Argentina, by using liquid chromatographymass spectrometry. J Agric Food Chem 65: 8184-8195 (2017).

6. Yousfi K, Cert RM, and García JM, Changes in quality and phenolic compounds of virgin olive oils during objectively described fruit maturation. Eur Food Res Technol 223: 117-124 (2006).

7. Rondanini DP, Castro DN, Searles PS, and Rousseaux MC, Contrasting patterns of fatty acid composition and oil accumulation during fruit growth in several olive varieties and locations in a non-Mediterranean region. Eur J Agron 52: 237-246 (2014).

8. García-Inza GP, Castro DN, Hall AJ, and Rousseaux MC, Responses to temperature of fruit dry weight, oil concentration, and oil fatty acid composition in olive (Olea europaea L. var. 'Arauco'). Eur J Agron 54: 107-115 (2014).

9. Trentacoste ER, and Puertas CM, Phenological characterization of Mendoza (Argentina) olive (Olea europaea L.) germplasm. Acta Hortic 949: 71-75 (2012).

10. Trentacoste ER, Puertas CM, and Sadras VO, Modelling the intraspecific variation in the dynamics of fruit growth, oil and water concentration in olive (Olea europaea L.). Eur J Agron 38: 83-93 (2012).

11. Sanzani SM, Schena L, Nigro F. Sergeeva V, Ippolito A, and Salerno MG, Abiotic diseases of olive. J Plant Pathol 94: 469-491 (2012). 
12. Caponio F, Gomes T, and Pasqualone A, Phenolic compounds in virgin olive oils: influence of the degree of olive ripeness on organoleptic characteristics and shelf-life. Eur Food Res Technol 212: 329-333 (2001).

13. Morelló JR, Motilva MJ, Ramo T, and Romero MP, Effect of freeze injuries in olive fruit on virgin olive oil composition. Food Chem 81: 547-553 (2003).

14. Avidan B, Ogrodovitch A, and Lavee S, A reliable and rapid shaking extraction system for determination of the oil content in olive fruit. Acta Hortic 474: 653658 (1999).

15. International Olive Council (IOC) Trade standard applying to olive oils and olivepomace oils (2015) COI/T.15/NC No: 3/Rev: 8.

16. Vázquez-Roncero A, Janer del Valle C, and Janer del Valle L, Determinación de los polifenoles totales en aceite de oliva. Grasas Aceites 24: 350-357 (1973).

17. International Olive Council (IOC). Determination of Biophenols in Olive Oils by HPLC. In COI/T.20/Doc No 29/Rev.1 (2017).

18. International Olive Council. Preparation of the fatty acid methyl esters from olive oil and olive-pomace oil. In COI/T.20/Doc $n^{\circ} 24$ (2001).

19. Trentacoste ER, Puertas CM, and Sadras VO, Effect of fruit load on oil yield components and dynamics of fruit growth and oil accumulation in olive (Olea europaea L.). Eur J Agron 32: 249-254 (2010).

20. Beltrán G, del Río C, Sánchez S, and Martínez L, Seasonal changes in olive fruit characteristics and oil accumulation during ripening process. J Sci Food Agric 84: 1783-1790 (2004). 
21. Baccouri O, Guerfel M, Baccouri B, Cerretani L, Bendini A, Lercker G, Zarrouk M, and Miled DDB, Chemical composition and oxidative stability of Tunisian monovarietal virgin olive oils with regard to fruit ripening. Food Chem 109: 743754 (2008).

22. Dag A, Kerem Z, Yogev N, Zipori I, Lavee S, and Ben-David E, Influence of time of harvest and maturity index on olive oil yield and quality. Sci Hortic 127: 358-366 (2011).

23. Benito M, Lasa JM, Gracia P, Oria R, Abenoza M, Varona L, and Sánchez-Gimeno AC, Olive oil quality and ripening in super-high-density Arbequina orchard. $J$ Sci Food Agric 93: 2207-2220 (2013).

24. Tayfun Agar I, Hess-Pierce B, Sourour MM, and Kader AA, Quality of fruit and oil of black-ripe olives is influenced by cultivar and storage period. J Agric Food Chem 46: 3415-3421 (1998).

25. Bengana M, Bakhouche A, Lozano-Sánchez J, Amir Y, Youyou A, SeguraCarretero A, and Fernández-Gutiérrez A, Influence of olive ripeness on chemical properties and phenolic composition of Chemlal extra-virgin olive oil. Food Res Int 54: 1868-1875 (2013).

26 Morelló JR, Romero MP, and Motilva MJ, Influence of seasonal conditions on the composition and quality parameters of monovarietal virgin olive oils. J Am Oil Chem Soc 83: 683-690 (2006).

27. Morelló JR, Romero MP, and Motilva MJ, Effect of the maturation process of the olive fruit on the phenolic fraction of drupes and oils from Arbequina, Farga, and Morrut cultivars. J Agric Food Chem 52: 6002-6009 (2004). 
28. Rotondi A, Bendini A, Cerretani L, Matteo M, Lercker G, and Gallina Toschi T, Effect of olive ripening degree on the oxidative stability and organoleptic properties of cv. Nostrana di Brisighella extra virgin olive oil. J Agric Food Chem 52: 3649-3654 (2004).

29. Ceci LN and Carelli AA, Characterization of monovarietal argentinian olive oils from new productive zones. J Am Oil Chem Soc 84: 1125-1136 (2007). 
Table 1. Fruit and oil characteristics (mean \pm standard deviation) from autochthonous cv Arauco harvested at different times during 2006-2007, 2007-2008, and 2008-2009 seasons in Junín, Mendoza, Argentina.

\begin{tabular}{|c|c|c|c|c|c|c|c|}
\hline $\begin{array}{l}\text { Harvest } \\
\text { date }\end{array}$ & Maturity index & $\begin{array}{l}\text { Fruit oil } \\
\text { (\% Fresh } \\
\text { Basis) }\end{array}$ & $\begin{array}{l}\text { Fruit oil } \\
\text { (\% Dry } \\
\text { Basis) }\end{array}$ & $\begin{array}{l}\text { Fruit water } \\
\text { (\%) }\end{array}$ & $\begin{array}{l}\text { Acidity } \\
(\%)\end{array}$ & $\begin{array}{l}\text { Oxidative } \\
\text { stability (h) }\end{array}$ & $\begin{array}{l}\text { Phenolic } \\
\text { Compounds } \\
\left(\mathrm{mg} \mathrm{kg}^{-1}\right)\end{array}$ \\
\hline \multicolumn{8}{|c|}{$2006-2007$} \\
\hline 20 April & $1.58 \pm 0.07 \mathrm{c}$ & $16.7 \pm 0.6 \mathrm{~cd}$ & $45.3 \pm 0.1$ & $63.0 \pm 0.7 a$ & $0.17 \pm 0.01 b$ & $13.3 \pm 1.2 \mathrm{a}$ & $438 \pm 66 a$ \\
\hline 7 May & $2.36 \pm 0.44 b c$ & $16.2 \pm 0.8 d$ & $44.3 \pm 3.1$ & $63.3 \pm 1.4 a$ & $0.29 \pm 0.04 a$ & $13.7 \pm 0.4 a$ & $378 \pm 5 a b$ \\
\hline 22 May & $2.51 \pm 0.46 b c$ & $20.2 \pm 1.8 b$ & $51.5 \pm 3.5$ & $60.9 \pm 0.9 b$ & $0.18 \pm 0.02 b$ & $11.7 \pm 1.5 \mathrm{ab}$ & $422 \pm 1 a$ \\
\hline 5 June & $3.58 \pm 1.31 \mathrm{ab}$ & $19.7 \pm 3.1 b c$ & $47.4 \pm 5.4$ & $58.5 \pm 1.8 b$ & $0.30 \pm 0.07 a$ & $10.5 \pm 2.0 \mathrm{bc}$ & $286 \pm 85 b$ \\
\hline 5 July & $3.87 \pm 1.03 a$ & $24.2 \pm 1.5 a$ & $49.8 \pm 1.3$ & $51.4 \pm 0.9 c$ & $0.24 \pm 0.05 a b$ & $8.1 \pm 1.4 \mathrm{c}$ & $60 \pm 2 c$ \\
\hline \multicolumn{8}{|c|}{$2007-2008$} \\
\hline 2 May & $1.04 \pm 0.02$ & $14.8 \pm 1.0 c$ & $37.5 \pm 2.2 b$ & $60.5 \pm 0.7 a$ & $0.17 \pm 0.02$ & $19.7 \pm 2.5 a$ & $453 \pm 41 a$ \\
\hline 22 May & $1.09 \pm 0.07$ & $17.3 \pm 0.7 b$ & $41.5 \pm 0.9 a$ & $58.4 \pm 0.8 b$ & $0.21 \pm 0.01$ & $22.2 \pm 1.7 a$ & $495 \pm 40 a$ \\
\hline 19 June & $1.11 \pm 0.10$ & $20.8 \pm 1.0 a$ & $44.2 \pm 1.3 a$ & $53.0 \pm 0.9 c$ & $0.29 \pm 0.02$ & $10.9 \pm 1.2 b$ & $273 \pm 29 b$ \\
\hline \multicolumn{8}{|c|}{$2008-2009$} \\
\hline 13 May & $1.65 \pm 0.11 b$ & $22.9 \pm 1.6$ & $52.2 \pm 3.2$ & $56.2 \pm 1.6$ & $0.21 \pm 0.02$ & $19.4 \pm 0.7 a$ & $585 \pm 1 a$ \\
\hline 3 June & $1.91 \pm 0.12 b$ & $21.5 \pm 3.4$ & $49.7 \pm 7.2$ & $56.8 \pm 0.7$ & $0.18 \pm 0.02$ & $17.2 \pm 1.8 \mathrm{a}$ & $444 \pm 2 b$ \\
\hline 3 July & $2.77 \pm 0.63 a$ & $24.0 \pm 4.9$ & $49.4 \pm 8.0$ & $51.6 \pm 4.5$ & $0.25 \pm 0.05$ & $11.5 \pm 1.6 b$ & $278 \pm 25 c$ \\
\hline
\end{tabular}

For each season, means with the same letter are not significantly different within each row by LSD test at $P \leq 0.05$. Letters are only showed when ANOVA indicates a significant harvest time effect. 
Table 2. Fruit and oil characteristics (mean \pm standard deviation) from autochthonous cv Arauco harvested at different times during $2015-2016$ and 2016-2017 seasons in Rivadavia, Mendoza, Argentina.

\begin{tabular}{|c|c|c|c|c|c|c|c|c|c|}
\hline $\begin{array}{l}\text { Harvest } \\
\text { date }\end{array}$ & $\begin{array}{l}\text { Maturity } \\
\text { index }\end{array}$ & $\begin{array}{l}\text { Fruit oil } \\
\text { (\% Fresh } \\
\text { Basis) }\end{array}$ & $\begin{array}{l}\text { Fruit oil } \\
\text { (\% Dry } \\
\text { Basis) }\end{array}$ & $\begin{array}{l}\text { Fruit water } \\
(\%)\end{array}$ & $\begin{array}{l}\text { Acidity } \\
(\%)\end{array}$ & $\begin{array}{l}\text { Oxidative } \\
\text { stability (h) }\end{array}$ & $\mathrm{K}_{232}$ & $\mathrm{~K}_{270}$ & $\begin{array}{l}\text { Phenolic } \\
\text { compounds } \\
\text { (mg kg-1) }\end{array}$ \\
\hline \multicolumn{10}{|c|}{$2015-2016$} \\
\hline 13 April & $1.23 \pm 0.10 b$ & $12.2 \pm 0.8 b$ & $43.7 \pm 3.0$ & $65.6 \pm 1.2 a$ & $0.44 \pm 0.04 a$ & $7.6 \pm 1.6 a$ & $0.27 \pm 0.10 b$ & $0.02 \pm 0.02$ & $488 \pm 104 a$ \\
\hline 17 May & $2.68 \pm 0.18 a$ & $15.4 \pm 0.6 a$ & $50.0 \pm 1.0$ & $66.2 \pm 0.8 a$ & $0.20 \pm 0.04 b$ & $7.6 \pm 0.2 a$ & $0.55 \pm 0.04 a$ & $0.07 \pm 0.02$ & $391 \pm 41 a b$ \\
\hline 18 June & $2.92 \pm 0.60 a$ & $13.2 \pm 1.4 b$ & $45.4 \pm 3.7$ & $62.4 \pm 1.3 b$ & $0.20 \pm 0.03 b$ & $5.8 \pm 1.0 b$ & $0.58 \pm 0.04 a$ & $0.05 \pm 0.01$ & $280 \pm 63 b$ \\
\hline \multicolumn{10}{|c|}{ 2016-2017 } \\
\hline 18 April & $0.65 \pm 0.19 b$ & $13.3 \pm 0.5 b$ & $46.6 \pm 0.9 b$ & $65.0 \pm 0.2 a$ & $0.20 \pm 0.01 a$ & $5.9 \pm 0.5 b$ & $1.48 \pm 0.11$ & $0.04 \pm 0.02 b$ & $445 \pm 103$ \\
\hline 9 May & $1.70 \pm 0.59 a$ & $14.1 \pm 1.4 b$ & $49.8 \pm 1.9 a$ & $66.0 \pm 1.8 a$ & $0.13 \pm 0.02 b$ & $7.9 \pm 0.3 a$ & $1.67 \pm 0.32$ & $0.11 \pm 0.08 a$ & $439 \pm 63$ \\
\hline 13 June & $2.22 \pm 0.41 \mathrm{a}$ & $15.7 \pm 0.8 a$ & $48.1 \pm 1.6 a b$ & $62.2 \pm 0.6 b$ & $0.11 \pm 0.02 b$ & $5.4 \pm 0.7 b$ & $1.49 \pm 0.42$ & $0.14 \pm 0.11 a$ & $410 \pm 151$ \\
\hline
\end{tabular}

For each season, means with the same letter are not significantly different within each row by LSD test at $P \leq 0.05$. Letters are only showed when ANOVA indicates a significant harvest time effect. 
Table 3. Major fatty acid (mean \pm standard deviation) from autochthonous cv Arauco harvested at different times during 2006-2007, 2007-2008 and 2008-2009 seasons in Junín, Mendoza, Argentina.

\begin{tabular}{|c|c|c|c|c|c|c|c|c|}
\hline $\begin{array}{l}\text { Harvest } \\
\text { date }\end{array}$ & $\begin{array}{l}\text { Palmitic } \\
\text { acid (\%) }\end{array}$ & $\begin{array}{l}\text { Palmitoleic } \\
\text { acid }(\%)\end{array}$ & $\begin{array}{l}\text { Stearic } \\
\text { acid (\%) }\end{array}$ & $\begin{array}{l}\text { Oleic } \\
\text { acid (\%) }\end{array}$ & $\begin{array}{l}\text { Linoleic } \\
\text { acid (\%) }\end{array}$ & $\begin{array}{l}\text { Linolenic } \\
\text { acid (\%) }\end{array}$ & $\begin{array}{l}\text { MUFA/ } \\
\text { PUFA }^{\text {a }}\end{array}$ & UFA/SFA ${ }^{b}$ \\
\hline \multicolumn{9}{|c|}{$2006-2007$} \\
\hline 20 April & $16.9 \pm 0.1 \mathrm{a}$ & $1.7 \pm 0.1 \mathrm{ab}$ & $2.4 \pm 0.41 c$ & $62.4 \pm 0.8 b c$ & $14.8 \pm 0.7 b$ & $0.83 \pm 0.02$ & $4.1 \pm 0.2 b c$ & $4.0 \pm 0.02 c$ \\
\hline 7 May & $15.6 \pm 0.1 b$ & $1.3 \pm 0.1 c$ & $2.6 \pm 0.02 a$ & $66.0 \pm 0.2 a$ & $12.6 \pm 0.3 c$ & $0.80 \pm 0.04$ & $5.0 \pm 0.1 a$ & $4.3 \pm 0.05 b$ \\
\hline 22 May & $15.6 \pm 0.2 b$ & $1.5 \pm 0.1 b c$ & $2.5 \pm 0.05 b$ & $65.1 \pm 0.6 a b$ & $13.5 \pm 0.5 b c$ & $0.78 \pm 0.02$ & $4.7 \pm 0.2 \mathrm{ab}$ & $4.3 \pm 0.04 b$ \\
\hline 5 June & $16.10 .9 \mathrm{ab}$ & $1.8 \pm 0.3 a$ & $2.5 \pm 0.08 b$ & $61.3 \pm 3.0 \mathrm{c}$ & $16.6 \pm 1.8 a$ & $0.80 \pm 0.15$ & $3.7 \pm 0.6 c$ & $4.2 \pm 0.23 c$ \\
\hline 5 July & $14.5 \pm 0.8 \mathrm{c}$ & $1.4 \pm 0.1 c$ & $2.6 \pm 0.03 a$ & $65.5 \pm 1.3 a b$ & $14.2 \pm 0.4 b c$ & $0.74 \pm 0.01$ & $4.5 \pm 0.2 \mathrm{ab}$ & $4.6 \pm 0.22 a$ \\
\hline \multicolumn{9}{|c|}{$2007-2008$} \\
\hline 2 May & $15.0 \pm 0.3 a$ & $1.2 \pm 0.1$ & $2.6 \pm 0.06 b$ & $70.1 \pm 0.9$ & $9.0 \pm 0.4 c$ & $1.00 \pm 0.06 a$ & $7.2 \pm 0.4 a$ & $4.4 \pm 0.09$ \\
\hline 22 May & $14.7 \pm 0.1 \mathrm{ab}$ & $1.2 \pm 0.1$ & $2.8 \pm 0.06 a$ & $69.8 \pm 0.3$ & $9.6 \pm 0.2 b$ & $0.90 \pm 0.06 b$ & $6.8 \pm 0.1 \mathrm{ab}$ & $4.5 \pm 0.03$ \\
\hline 19 June & $14.4 \pm 0.1 b$ & $1.2 \pm 0.1$ & $2.8 \pm 0.01 a$ & $69.5 \pm 0.1$ & $10.3 \pm 0.1 \mathrm{a}$ & $0.80 \pm 0.01 b$ & $6.4 \pm 0.1 b$ & $4.6 \pm 0.03$ \\
\hline \multicolumn{9}{|c|}{ 2008-2009 } \\
\hline 13 May & $16.2 \pm 0.2 a$ & $1.5 \pm 0.1$ & $2.8 \pm 0.06$ & $64.9 \pm 0.6 a$ & $12.9 \pm 0.4 b$ & $0.50<0.01$ & $5.0 \pm 0.2 a$ & $4.0 \pm 0.03 b$ \\
\hline 3 June & $15.8 \pm 0.2 \mathrm{ab}$ & $1.4 \pm 0.1$ & $2.8 \pm 1.11$ & $61.6 \pm 0.9 b$ & $13.5 \pm 0.8 b$ & $0.50<0.01$ & $4.7 \pm 0.3 a$ & $4.1 \pm 0.03 b$ \\
\hline
\end{tabular}



3 July
$15.4 \pm 0.3 b$
$1.5 \pm 0.1$
$2.8 \pm 0.17$
$63.1 \pm 0.6 a$
$15.5 \pm 0.7 a$
$0.50<0.01$
$4.1 \pm 0.2 b$
$4.2 \pm 0.08 \mathrm{a}$

${ }^{a}$ MUFA/PUFA: monounsaturated fatty acids/polyunsaturated fatty acids; ${ }^{b}$ UFA/SFA: unsaturated fatty acids/saturated fatty acids

For each season, means with the same letter are not significantly different within each row by LSD test at $P \leq 0.05$. Letters are only showed when ANOVA indicates a significant harvest time effect. 
Table 4. Major fatty acids (mean \pm standard deviation) from autochthonous cv Arauco harvested at different times during 2015-2016 and 20162017 seasons in Rivadavia, Mendoza, Argentina.

\begin{tabular}{|c|c|c|c|c|c|c|c|c|}
\hline $\begin{array}{l}\text { Harvest } \\
\text { date }\end{array}$ & $\begin{array}{l}\text { Palmitic } \\
\text { acid (\%) }\end{array}$ & $\begin{array}{l}\text { Palmitoleic } \\
\text { acid }(\%)\end{array}$ & $\begin{array}{l}\text { Stearic } \\
\text { acid (\%) }\end{array}$ & $\begin{array}{l}\text { Oleic } \\
\text { acid (\%) }\end{array}$ & $\begin{array}{l}\text { Linoleic } \\
\text { acid }(\%)\end{array}$ & $\begin{array}{l}\text { Linolenic } \\
\text { acid (\%) }\end{array}$ & $\begin{array}{l}\text { MUFA/ } \\
\text { PUFAa }\end{array}$ & UFA/SFAb \\
\hline \multicolumn{9}{|c|}{$2015-2016$} \\
\hline 13 April & $18.3 \pm 0.2 \mathrm{a}$ & $2.1 \pm 0.08 b$ & $2.2 \pm 0.02 b$ & $61.5 \pm 0.3 b$ & $13.7 \pm 0.1 b$ & $1.20 \pm 0.01 a$ & $4.3 \pm 0.1 b$ & $3.7 \pm 0.04 c$ \\
\hline 17 May & $17.6 \pm 0.2 b$ & $2.4 \pm 0.05 a$ & $2.2 \pm 0.02 b$ & $60.1 \pm 0.1 c$ & $15.5 \pm 0.1 a$ & $1.13 \pm 0.04 b$ & $3.8 \pm 0.1 c$ & $3.9 \pm 0.03 b$ \\
\hline 18 June & $16.2 \pm 0.3 c$ & $2.2 \pm 0.12 b$ & $2.3 \pm 0.03 a$ & $64.0 \pm 0.4 a$ & $13.2 \pm 0.1 \mathrm{c}$ & $1.00 \pm 0.04 c$ & $4.7 \pm 0.1 \mathrm{a}$ & $4.2 \pm 0.08 a$ \\
\hline \multicolumn{9}{|c|}{ 2016-2017 } \\
\hline 13 April & $17.8 \pm 0.2$ & $1.7 \pm 0.01 b$ & $2.5 \pm 0.01 \mathrm{a}$ & $60.8 \pm 0.5$ & $14.8 \pm 0.2$ & $1.10 \pm 0.01$ & $3.9 \pm 0.1$ & $3.7 \pm 0.06$ \\
\hline 9 May & $18.5 \pm 1.1$ & $1.9 \pm 0.10 b$ & $2.3 \pm 0.13 b$ & $59.3 \pm 1.6$ & $15.8 \pm 1.3$ & $0.97 \pm 0.29$ & $3.7 \pm 0.3$ & $3.6 \pm 0.25$ \\
\hline 13 June & $17.3 \pm 0.8$ & $2.2 \pm 0.10 a$ & $2.2 \pm 0.11 b$ & $60.0 \pm 0.9$ & $16.2 \pm 0.3$ & $1.01 \pm 0.03$ & $3.6 \pm 0.1$ & $4.0 \pm 0.11$ \\
\hline
\end{tabular}

aMUFA/PUFA: monounsaturated fatty acids/polyunsaturated fatty acids; ${ }^{\mathrm{a} U F A / S F A}$ : unsaturated fatty acids/saturated fatty acids. For each year, means with the same letter are not significantly different within each row by LSD test at $P \leq 0.05$. Letters are only showed when ANOVA indicates a significant harvest time effect. 

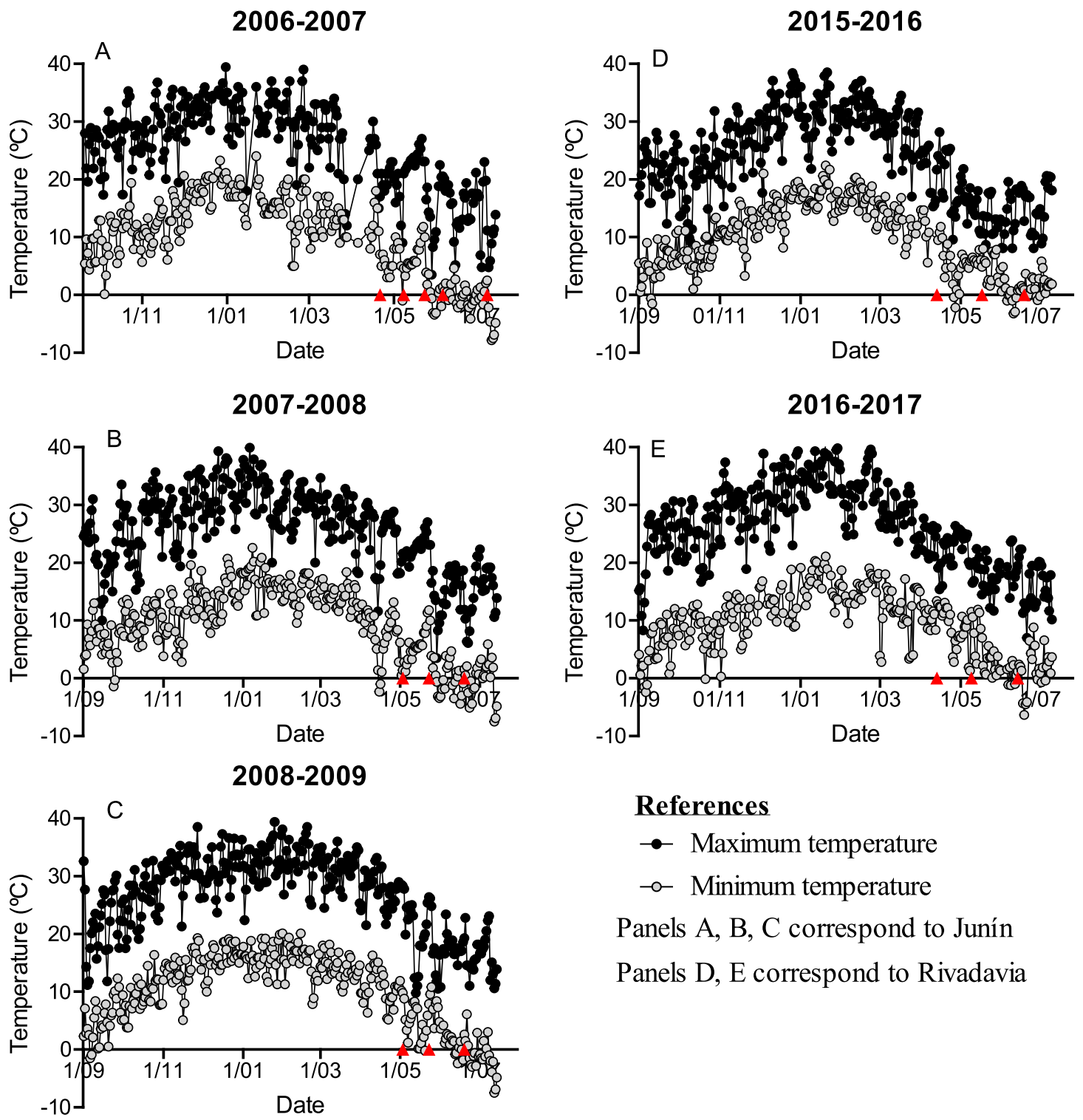

\section{References \\ $\rightarrow$ Maximum temperature \\ - - Minimum temperature}

Panels A, B, C correspond to Junín

Panels D, E correspond to Rivadavia

Fig. 1. Daily maximum and minimum air temperature during studied growing seasons in two locations: Junín (A, B and D) and Rivadavia ( $D$ and $E$ ) in Mendoza province. Red arrows indicate different harvest days. 

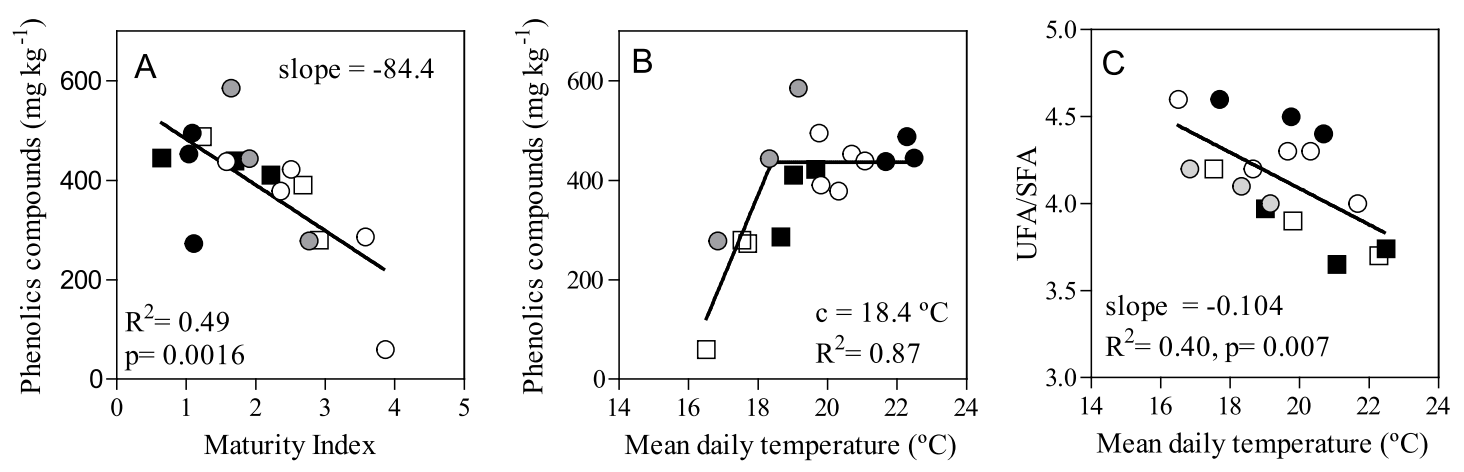

Fig. 2. Relationships between phenolic content with maturity index (A) and mean daily temperature during the fruit oil accumulation period (January to harvest day) (B).

Relationships between unsaturated/saturated fatty acids (UFA/SFA) ratio and temperature during the fruit oil accumulation period $(C)$ in olive oil extracted from fruits of cv Arauco at different harvest dates in two locations Junín (circles) and Rivadavia (squares) of Mendoza province. 